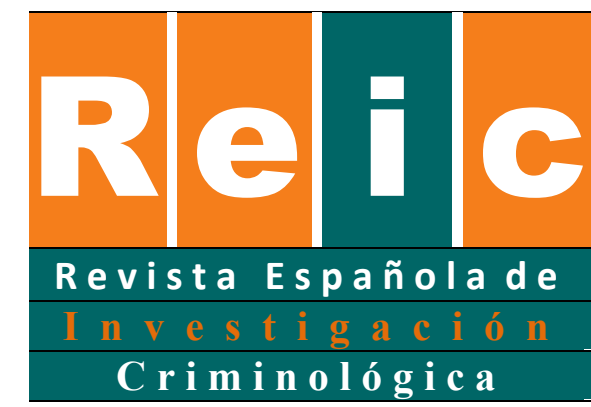

\title{
Getting Started with the Mainstreaming of Therapeutic Jurisprudence in Criminal Cases: Tips on How and Where to Begin
}

\section{Empezando con los principios de la Justicia Terapéutica en casos penales: Consejos sobre cómo y dónde comenzar}

\author{
David B. Wexler ${ }^{1}$ \\ University of Puerto Rico
}

\begin{abstract}
Therapeutic Jurisprudence ("TJ") is a perspective that looks at the law itself as a potential therapeutic (or anti-therapeutic) agent. Under TJ, the "law" consists of legal rules and procedures as well as the practices and techniques of legal actors (judges, lawyers, therapists and others) working in a legal environment. TJ is best known for its use in special 'problem-solving courts', such as drug treatment courts and mental health courts. Now, however, an effort is being made internationally - to "mainstream" TJ: to bring therapeutic jurisprudence practices into the "ordinary" criminal justice legal system. The current monograph offers a guide to how the mainstreaming project should proceed, and, especially, offers some suggestions for where in the process we might most profitably begin.
\end{abstract}

\footnotetext{
${ }^{1}$ Professor of Law and Director, International Network on Therapeutic Jurisprudence, University of Puerto Rico; Distinguished Research Professor of Law Emeritus, Rogers College of Law, University of Arizona. DavidBwexler@yahoo.com Thanks to Rocio Alonso for her able research assistance and to Prof. Constance Backhouse for her encouragement during the entire course of this project. Professor Backhouse, a legal historian, has also written a short biographical essay concentrating on my academic life and the origin and development of therapeutic jurisprudence. See http://ssrn.com/abstract=2747488.
} 
Keywords: Therapeutic Jurisprudence, Law, Justice

\section{RESUMEN}

La Justicia Terapéutica (“TJ") es una perspectiva conceptual que analiza la legislación en términos de su potencial o capacidad terapéutica (o anti-terapéutica). Para la TJ el concepto de "ley" incluye tanto las normas y procedimientos jurídicos como también las prácticas y técnicas desarrolladas por los operadores que intervienen en la Justicia (jueces, abogados, terapeutas y otros). Los ámbitos más explorados de intervención mediante TJ son los correspondientes a los denominados en el ámbito anglosajón como "tribunales especiales de resolución de problemas", entre los que se encuentran los tribunales para el tratamiento de las adicciones y los dirigidos a salud mental. En unión a ello, en la actualidad se está intentando desarrollar la TJ, tanto en Estados Unidos como internacionalmente, también en el marco de la justicia penal ordinaria (más allá de los ámbitos originarios de drogas y salud mental). Esta monografía ofrece una guía para la aplicación de la TJ y diversas sugerencias para mejorar su utilidad.

Palabras clave: Justicia Terapéutica, ley, justicia

\section{Therapeutic Jurisprudence}

Therapeutic Jurisprudence (TJ) looks at the law as a potential therapeutic agent, and defines "the law" as consisting of Legal Rules and Procedures (the Legal Landscape or Structure) as well as the Roles (Practices and Techniques) of legal actors - such as judges, lawyers, therapists and correctional professionals working in the legal arena-(Wexler, 2010) ${ }^{2}$.

Early on, TJ was largely embraced by "problem -"solving" or "solution-focused" courtscourts (such as drug treatment courts, mental health courts, and, more recently, veterans courts) that are structured to invite the robust use of therapeutic practices such as active empathic

\footnotetext{
${ }^{2}$ There is a Spanish language version of my paper -an introduction to therapeutic jurisprudence- available online at http://ssrn.com/abstract=2468365. In terms of "mainstreaming" TJ into the general criminal justice system, there is one of my own papers available ("Nuevo Vino en Nuevas Botellas") at http://ssrn.com/abstract=2466124, and a coauthored paper (with Manuel Perez) on the "viñedo" of TJ at http://ssrn.com/abstract=278387.

Two other papers in Spanish, relating to the mainstreaming project as applied to the youth code of Puerto Rico, are (by Michael Ramos) at http://ssrn.com/abstract $=2400129$ and (by Paola Sepulveda-Miranda) at http://ssrn.com/abstract=2766629. There is an extensive bibliography of therapeutic jurisprudence at www.therapeuticjurisprudence.org, with the great majority of articles in English, but with a growing collection in Spanish (and occasional pieces in 10 or more languages) interested readers can search under Spanish to see an assortment of TJ articles.
} 
judicial listening and according the parties meaningful voice and engaged participation (Winick \& Wexler, 2003).

Now, propelled by the relative success of and enthusiasm for many of the problemsolving courts, the TJ community - myself very much included- has turned its attention to the "mainstreaming" of therapeutic jurisprudence: the expansion of the use of psychologicallysuggested TJ practices in the "ordinary" legal arena, especially in criminal and juvenile cases (Buss, 2016; Fondacaro, Koppel, O’Toole, \& Crain, 2015; Jones, 2012; Segev, 2014; Spencer, 2014; Wexler, 2014a), and even beyond (Vols, 2014).

The mainstreaming effort has been facilitated by a metaphor and a methodology that views the legal structures as "bottles" and the desirable TJ practices and techniques as "liquid" or "wine" (Wexler, 2014a). And mainstreaming is especially endorsed by a recent article urging court systems interested in the International Framework on Court Excellence, www.courtexcellence.com, to explicitly add to their agenda the promotion of "wellbeing" through the use of TJ (Richardson, Spencer, \& Wexler, 2016).

The wine/bottle metaphor asks us to examine whether the existing "bottles" are sufficiently "TJ-friendly" to allow for the easy introduction of an ample amount of good TJ wine. If not, we should ask whether the law could be plausibly reformed to increase the potential amount of the wine. The process of reforming a legal provision itself is known as the Therapeutic Design of the Law (TDL). If the law would allow for a decent amount of the wine, we should then ascertain if the law is in fact being applied in a therapeutic way -the Therapeutic Application of the Law (TAL)-. If not, we should consider which legal actors should be encouraged to use the TJ techniques, and how they should be educated to do so (Wexler, 2015).

For clarity, let me quickly give an example of TDL and TAL. In Victoria, Australia, courts issuing a "community corrections order" were in the past legally unable to hold follow-up hearings to monitor compliance with the conditions imposed. An amendment to the law was accordingly recommended and enacted, providing us with an easy example of TDL (Wexler, 2014a, p.465).

On the TAL side, let us consider a judge imposing a probationary sentence. One way of imposing such a sentence without using much TJ wine would be for the judge to read the Revista Española de Investigación Criminológica

Monografía 1, Número 14 (2016)

Www.criminologia.net

ISSN: 1696-9219 
probation officer's presentence report and recommendation and then simply -unilaterally- to impose probation and its conditions. An alternative way, however -one that would be a good example of TAL- would be to ask the offender why a probationary sentence might be appropriate, what conditions might be called for, why the judge should feel confident that probation would succeed, how this time is different from a past incident where probation did not succeed, and so on. In this example, both manners of sentence/probation imposition would be possible under the design of the law, but only the second approach would avail itself of the psychological/criminological $\mathrm{TJ}$ knowledge that suggests the second way would be perceived by the offender as more just -and would likely lead to greater compliance with the conditions-. This example, incidentally, underscores the importance of psychology, criminology, and social work as "vineyards" that produce the recommended TJ wine (Wexler, 2016).

By now, it should be obvious that I am a great enthusiast of TJ "mainstreaming", and am actively involved in the $\mathrm{TJ}$ in the Mainstream Blog edited by Victoria magistrate Pauline Spencer, and I urge readers to join at www.mainstreamtj.wordpress.com. The Blog is a userfriendly and ongoing resource designed to promote the use of $\mathrm{TJ}$ in the mainstream.

Given my involvement in TJ mainstreaming, it should similarly be obvious why I was jarred, only a few days ago, when I read the title of an article in Judicature by an experienced author (and friend), Victor E. ("Gene") Flango, entitled Why Problem-Solving Principles Should Not be Grafted onto Mainstream Courts (Flango, 2016)! I of course read Gene's article without delay. And I am pleased to report that I am now able once again to take a deep breath, relax, and indeed to return to the mainstreaming project with renewed energy and insight. That is because I find that, in considering Flango's argument, I now have a clearer view -actually a reinforced earlier view- of how and where to focus the mainstreaming effort.

As I understand it, Flango's broad-brushed and sweeping thesis basically boils down to the simple statement that we should not mix "the competing goals of rehabilitation and punishment in criminal cases" (p32). We should thus have an adversarial adjudicatory system leading to "like cases treated alike" punishment. And, if we are going to attempt rehabilitative resolutions, we should construct another track -a problem-solving non-adversarial "medical model"- for those who have admitted guilt and are triaged into a TJ-type arena. 
Whatever one might think of Flango's ultimate solution (Bierschbach \& Bibas, 2016), to me it surely should not derail a genuine attempt to graft, wherever feasible, a TJ approach to our existing admittedly "mixed" criminal justice system. Our "adversarial" system, in the United States at least, leads in $95 \%$ of the cases to a result reached not through trial but instead through plea negotiation. There is little argument that the plea process is an untamed, largely under-the radar disgrace (Bibas, 2003). As we shall see below, it can unquestionably be improved through some TJ grafting efforts (Jones, 2012).

Sentencing systems have traditionally blended -or at least "juggled" - elements of rehabilitation and punishment. Law students have always been able easily to recite the "purposes" of criminal law sentencing as including rehabilitation, deterrence, restraint, and retribution (desert) (Spencer, 2014). TJ has in fact played a significant role in helping judges to become better jugglers and, in many appropriate instances, to achieve very meaningful rehabilitative results (Jones, 2012; Spencer, 2014).

As it turns out, Flango's concerns about the problem-solving approach echo concerns that were, to me, quieted by the realization that due process worries are not paramount in certain significant stages of the criminal process. And it is largely these processes where TJ grafting can rather comfortably occur. In an earlier discussion of the mainstreaming project (Wexler, 2014b), I said: Not all stages of the process are ripe for major examination. For instance, the trial itself (which actually occurs in only about $5 \%$ of American cases), so long as it is conducted in line with basic precepts of respect and procedural justice, doesn't yield much to TJ insights. Instead, our focus is more on pre- or post-adjudication legal areas. There is actually an advantage to that limitation on focus, one noted even by a fairly vocal critic of problem-solving courts and justice -Professor Eric Miller- who has written: "I have so far avoided the major worry raised by the opponents of problem-solving justice: the attack on due process. In part, that is because I believe that, in the American context at least, structural features render this worry doctrinally marginal. It turns out that, since problem-solving justice is a form of pre- or post-adjudication monitoring of conditions of release, judicial discretion and judicial advocacy impacts many fewer constitutional rights than critics generally suppose (Miller, p.14, in Donoghue, 2014)". In line with Miller's observation, the Wine/Bottle paper (Wexler, 2014a) canvasses: 1) early-stage areas such as diversion, bail, criminal settlement conferences; 2) the post-adjudication stage of 
sentence imposition; and 3) later stages such as post-incarceration conditional release (e.g., parole) and even appeal.

\section{Implementing TDL and TAL in different jurisdictions}

These above areas are indeed the stages where mainstreaming efforts should "get started". In fact, notable TJ work has occurred regarding some of these stages. Here I will highlight, with principal references, pertinent scholarship so those interested in mainstreaming might more easily proceed to actually consider and implement TDL and TAL in their respective jurisdictions:

\subsection{Pleas and Criminal Settlement Conferences}

An important TJ critique of the plea bargaining process by Israeli law professor Rinet KitaiSangero, Plea Bargaining as Dialogue, underscores the absence of defendant participation in the process (Kitai-Sangero, 2015; See also: Alberstein \& Zimmerman, 2016). Judge/Professor Michael Jones from Arizona Summit Law School is a strong supporter of criminal settlement conferences, which he conducts with a heavy dose of TJ, introducing elements of mediation, restorative justice factors, victim and family participation, and the like (Jones, 2012). His home state of Arizona has a rule authorizing judicial mediation in criminal settlement conferences, but other jurisdictions (including the federal system in the United States) would need to engage in TDL to authorize judicial involvement in the plea negotiation process. Similarly, Wexler and Jones (2013), writing about the TJ-friendly Arizona rule, propose a therapeutic application of that rule (TAL) that includes proposed "scripts" that judges might consider using when they conduct such conferences. The whole idea of "scripts" as a new and important type of TJ legal writing is worth considering. Such methods of TAL are typically very welcome to the judiciary and can thus also foster the sustainability of the new therapeutic applications.

\subsection{Sentence Imposition}


The above topic of plea negotiations and criminal settlement conferences flows naturally into the topic of sentence imposition. After all, the matter of greatest concern in settlement conferences is typically the question of the sentence to be imposed. Sentence imposition is one of the more developed TJ topics, and the topic thrives in the "ordinary" criminal justice system (Spencer, 2012; Spencer, 2014; Wexler, 2001; Wexler, 2016). Both TDL and TAL are of importance.

Besides the big questions of sentencing structure itself (often a hot-button issue), lesser known-and far less controversial -provisions can also be important to TDL: A therapeuticallydesigned law, for example, would allow for the delayed imposition of sentence in appropriate cases, permitting the defendant (with the help of counsel) to explore some rehabilitative options that might get him/her on the right track and might ultimately lead to a lesser sentence than might be the case if sentence were imposed promptly. Another TDL factor would include the ability of a court to terminate early an imposed period of probationary supervision, an act that would underscore -and likely reinforce- the probationer's successful efforts.

And TAL is especially significant here, as it is not only the type of sentence itself that matters but also the method of sentence imposition that can impact the offender's compliance, sense of justice, and rehabilitative efforts. These methods flow from the psychological/ criminological "vineyards" of TJ, derived from branches of psychology such as procedural justice (according voice, validation, vibrant participation), relapse prevention planning (focusing on what went wrong and how to prevent those high-risk situations from reoccurring), health care compliance principles (the importance of avoiding a judicial fiat if language conveying a more bilateral arrangement can be crafted - in essence an informal behavioral contract), desistance research (underscoring strengths, praising compliance, recognizing achievement) (Wexler, 2016); these vineyards grow with the growth of psychology and related fields, and developmental psychology and neurology are now beginning to blossom in juvenile law (Buss, 2016; Fondacaro et al., 2015). Of particular importance in the area of sentencing is the work of Australia Magistrate Pauline Spencer (2014), the resource section for judges provided by the TJ in the Mainstream Blog, and the judicial training tapes produced by the Neighborhood Justice Centre of Victoria, at www.civiljustice.info/njc/. 
Much of the therapeutically-oriented sentence imposition material will deal with the possibility and viability of non-incarcerative sentences such as probation or community corrections orders, and much of it will have to do with judicial /participant conversation and dialogue (Wexler, 2016) as well as printed forms (prepared by counsel or the judge) designed to assist a participant in preparation for an upcoming sentencing hearing.

But even a serious sentence of punishment and incarceration can be imposed in a way to emphasize an offender's strengths, to motivate him/her toward the post-prison future, and to in essence serve as potential building blocks for that new post-incarceration life (Wexler, 2001). This underscores the point, counter to the view expressed by Flango, that mixing rehabilitative and punishment goals can indeed achieve some important goals. In fact, why in the world would anyone want simply to march on with a sentencing approach that would not try to graft these simple but valuable (perhaps transformative) TJ techniques?

\subsection{Post-incarceration Conditional Release Structures}

How well an incarcerated person does during imprisonment seemingly has at least something to do with the very design of the law that speaks to his or her eventual release. TDL, in other words, is of real importance here. Consider the therapeutically bankrupt United States federal supervised release system, where conditional release now occurs automatically.

This automatic system contrasts sharply with the older, traditional discretionary parolerelease system. In fact, a study of an American state that changed from the older, traditional system to the so-called "modern" federal model of automatic supervised release yielded some noteworthy findings: under the new system, inmates enrolled less often in voluntary educational/job preparation programs; they also had a greater number of disciplinary infractions during confinement; and their recidivism rates post-release was higher than those released under the older system (Herzog-Evans, 2015). Though not measured in the study, it is a good guess that the professional satisfaction levels of professional prison staff would be lower under the new system as well, since that system seems to sap the incarcerated population of motivation to engage in rehabilitative programming. 
It is interesting to compare these various release structures with the provisions common to Europe and Latin America where a separate judge handles the monitoring of a sentence and the awarding of conditional release (Herzog-Evans, 2015). The TDL of such a law seems preferable to the federal American model. An empirical examination of the actual operation of the law in various jurisdictions would, however, be necessary to answer the question regarding the vigor of TAL in the respective jurisdictions (Wexler, 2014a, p.473).

\subsection{Appellate Courts}

The great bulk of TJ work continues to be done in the lower courts. But there is surely room in the appellate arena for a TJ analysis and for improvement in court excellence. Some of this work might relate to TDL - for example whether appellate courts should even be permitted simply to affirm a conviction without giving any explanation at all (a summary per curiam affirmance) (Ronner \& Winick, 2000). But generally, the TJ element of appellate work will consist in opinion-writing. Here, a leading voice has been University of Ottawa Law Dean Nathalie Des Rosiers, who argued that appellate courts should write opinions less as congratulatory letters to winners and more as respectful letters to the loser (Des Rosiers, 2000). Des Rosiers argued that lawyering, too, should be done differently, and I have suggested how, given the difficulty of achieving that goal in the adversary system, law clerks may be the lawyers who can best help in that task (Wexler, 2012). There is much more that can be done here and, as with "scripts", mentioned earlier, TJ and legal writing needs to receive much more attention than it has so far (Cooney, 2015; Kierstead, 2015).

\section{Conclusion}

These remarks have merely scratched the surface, but I hope they point to illustrative ways in which the law can be designed -and especially applied- in a therapeutic manner without further ado. Many other stages of the proceedings and relevant literature could have been cited, but the examples listed here are ones where there is already a body of work that can be used in actual practice, and I hope they are examples that establish that some highly important therapeutic aims 
can be sought and achieved in the "ordinary" criminal law arena. I also hope interested readers will join the Blog and themselves contribute to the overall important and ongoing TJ mainstreaming project.

\section{References}

Alberstein, M., \& Zimerman, N. (2016). Constructive Plea Bargaining; Towards Judicial Conflict Resolution. Social Science Research Network, 1-20. Also available at http://ssrn.com/abstract $=2829289$

Bibas, S. (2003). Bringing Moral Values into a Flawed Plea Bargaining System. Cornell Law Review, 88(5), 1-11. Also available at http://ssrn.com/abstract=393962

Bierschbach, R. A., \& Bibas, S. (2016). What's Wrong With Sentencing Equality?. Virginia Law Review, 102(6), 101-179. Also available at http://ssrn.com/abstract=2821239

Buss, E. (2016). Developmental Jurisprudence. Temple Law Review, 88, 741-768.

Cooney, M. (2015). The Architecture of Clarity. The Clarity Journal, 73(1), 6-10. Also available at http://ssrn.com/abstract $=2803221$

Des Roisers, N. (2000). From Telling to Listening: A Therapeutic Analysis of the Role of Courts in Minority-Majority Conflicts. Court Review, 37, 54-62.

Donoghue, J. (2014). Transforming Criminal Justice? Problem-Solving and Court Specialisation. New York, NY: Routledge.

Flango, V. E. (2016). Why Problem-Solving Principles Should Not be Grafted onto Mainstream Courts. Judicature, 100(1), 30-36.

Fondacaro, M. R., Koppel, S., O’Toole, M. J., \& Crain, J. (2015). The Rebirth of Rehabilitation in Juvenile and Criminal Justice: New Wine in New Bottles. Ohio Northern University Law Review, 41, 697-730. Also available at http://ssrn.com/abstract=2603694

Herzog-Evans, M. (2015). Offender Release and Supervision: The Role of Courts and the Use of Discretion. Nijmegen: Wolf Legal Publishers.

Jones, M. D. (2012). Mainstreaming Therapeutic Jurisprudence into the Traditional Courts: Suggestions for Judges and Practitioners. Phoenix Law Review, 5(4), 753-775. Also available at http://ssrn.com/abstract $=2102375$

Kierstead, S. (2015). Legal Writing, Therapeutic Jurisprudence, and Professionalism. Suffolk University Law Online Review, 3(29), 29-35.

Kitai-Sangero, R. (2015). Plea-Bargaining as Dialogue. Akron Law Review, 49(1), 63-89. Also available at http://ssrn.com/abstract $=2701413$ 
Richardson, E., Spencer, P., \& Wexler, D. B. (2016). The International Framework for Court Excellence and therapeutic jurisprudence: Creating excellent court and enhancing wellbeing. Journal of Judicial Administration, 25(3), 148-166. Also available http://ssrn.com/abstract=2782162

Ronner, A. D., \& Winick, B. J. (2000). Silencing the Appellant's Voice: The Antitherapeutic Per Curiam Affirmance. Seattle University Law Review, 24, 499-507. Also available at http://ssrn.com/abstract $=274975$

Segev, D. (2014). The TJ Mainstreaming Project: An Evaluation of the Israeli Youth Act. The Arizona Law Review, 7(3), 527-538. Also available at http://ssrn.com/abstract $=2296538$

Spencer, P. (2012). To Dream the Impossible Dream? Therapeutic Jurisprudence in Mainstream Courts. In International Conference on Law and Society. Also available at http://ssrn.com/abstract $=2083370$

Spencer, P. (2014). From Alternative to the New Normal: Therapeutic Jurisprudence in the Mainstream. Alternative Law Journal, 39(4), 222-226. Also available at http://ssrn.com/abstract=2550157

Vols, M. (2014). Neighbors from Hell: Problem-Solving and Housing Laws in the Netherlands. The Arizona Summit Law Review, 7, 507-526. Also available at http://ssrn.com/abstract $=2425653$

Wexler, D. B., \& Jones, M. D. (2013). Employing the 'Last Best Offer' Approach in Criminal Settlement Conferences: The Therapeutic Application of an Arbitration Technique in Judicial Mediation. Phoenix Law Review, 6, 843-855. Also available at http://ssrn.com/abstract=2208050

Wexler, D. B. (2001). Robes and Rehabilitation: How Judges Can Help Offenders 'Make Good'. Court Review, 38(1), 18-23. Also available at http://ssrn.com/abstract=2719915

Wexler, D. B. (2010). Therapeutic Jurisprudence and its Application to Criminal Justice Research and Development. Irish Probation Journal, 7, 94-107. Also available at http://ssrn.com/abstract $=1628804$. Spanish version at http://ssrn.com/abstract $=2468365$

Wexler, D. B. (2012). Elevating Therapeutic Jurisprudence: Structural Suggestions for Promoting a Therapeutic Jurisprudence Perspective in the Appellate Courts. Phoenix Law Review, 5, 777-790. Also available at http://ssrn.com/abstract=2001046

Wexler, D. B. (2014a). New Wine in New Bottles: The Need to Sketch a Therapeutic Jurisprudence "Code" of Proposed Criminal Processes and Practices. Arizona Summit Law Review, 7, 463-479. Also available at http://ssrn.com/abstract=2466124

Wexler, D. B. (2014b). The International and Interdisciplinary Project to Mainstream Therapeutic Jurisprudence (TJ) in Criminal Courts: An Update, a Law School Component, and an Invitation. Alaska Journal of Dispute Resolution, 1-11. Also available at http://ssrn.com/abstract $=2399914$ 
Wexler, D. B. (2015). Moving Forward on Mainstreaming Therapeutic Jurisprudence: An Ongoing Process to Facilitate the Therapeutic Design and Application of the Law. Therapeutic Jurisprudence, (15-10), 1-9. Also available at http://ssrn.com/abstract $=2564613$

Wexler, D. B. (2016). Guiding Court Conversation Along Pathways Conducive to Rehabilitation: Integrating Procedural Justice and Therapeutic Jurisprudence. Arizona Legal Studies Discussion Paper, (15-33), 1-4. Also available at http://ssrn.com/abstract=2677431

Winick, B., \& Wexler, D. (2003). Judging in a Therapeutic Key: Therapeutic Jurisprudence and the Courts. Durham, NC: Carolina Academic Press. 